\title{
A Systematic Review of the Effects of Pilates Method of Exercise in Healthy People
}

\author{
Ana Cruz-Ferreira, MA, Jorge Fernandes, PhD, Luis Laranjo, MSc, Lisa M. Bernardo, PhD, \\ António Silva, PhD
}

ABSTRACT. Cruz-Ferreira A, Fernandes J, Laranjo L, Bernardo LM, Silva A. A systematic review of the effects of Pilates method of exercise in healthy people. Arch Phys Med Rehabil 2011;92:2071-81.

Objective: To evaluate evidence for the effectiveness of the Pilates method of exercise (PME) in healthy people.

Data Sources: Published research was identified by searching Science Direct, MEDLINE, PubMed, SPORTDiscus, PEDro, Cochrane Central Register of Controlled Trials, CINAHL, and Web of Science.

Study Selection: Research studies published from inception to May 7, 2011 were selected for evaluation. Two reviewers independently applied the inclusion criteria to selected potential studies. Studies were included if they were published in a peer-reviewed journal, written in the English language, conducted as a randomized controlled trial (RCT) or quasi-RCT in healthy people, had an inactive and/or exercise control group(s), included key study outcomes, and used the PME as the study intervention in at least 1 study arm.

Data Extraction: Two reviewers independently extracted data (study, design, subjects, intervention, key outcomes results), applied the Physiotherapy Evidence Database (PEDro) scale to assess the method quality of selected studies, and determined the strength of the evidence using the best evidence synthesis grading system.

Data Synthesis: Sixteen studies met the inclusion criteria. PEDro scale values ranged from 3 to 7 (mean, 4.1), indicating a low level of scientific rigor. The outcomes studied most often were flexibility, muscular endurance, strength, and postural alignment. The PME appears to be effective in improving flexibility (strong evidence), dynamic balance (strong evidence), and muscular endurance (moderate evidence) in healthy people.

Conclusions: There was strong evidence to support the use of the PME at least to the end of training to improve flexibility and dynamic balance and moderate evidence to enhance muscular endurance. Future RCTs should focus on the components of blinding, concealed allocation, subject adherence, intentionto-treat analysis, and follow-up designs.

From the Department of Sport and Health, Health Science and Technology Research Centre, University of Evora, Évora, Portugal (Cruz-Ferreira, Fernandes, Laranjo); University of Pittsburgh School of Nursing, Pittsburgh, PA (Bernardo); and the Research Center in Sports, Health Sciences and Human Development, Department of Sport Science, Exercise and Health, University of Trás-os-Montes e Alto Douro, Vila Real, Portugal (Silva).

No commercial party having a direct financial interest in the results of the research supporting this article has or will confer a benefit on the authors or on any organization with which the authors are associated.

Correspondence to Ana Cruz-Ferreira, MA, Dept of Sport and Health, University of Évora, Pavilhão Gimnodesportivo da Universidade de Evora, Rua de Reguengos de Monsaraz, $\mathrm{n}^{\circ} 44,7005-399$ Évora, Portugal, e-mail: anacruzferreira@gmail.com. Reprints are not available from the author.

0003-9993/11/9212-01132\$36.00/0

doi:10.1016/j.apmr.2011.06.018

Key Words: Pilates training; Rehabilitation; Studies method; Systematic review.

(C) 2011 by the American Congress of Rehabilitation Medicine

$\mathbf{T}$ HE PILATES METHOD was created by Joseph Pilates, who combined exercise/movement, philosophy, gymnastics, martial arts, yoga, and dance into an approach for healthy living. This program of mind-body exercise is based on 6 key principles: centering, concentration, control, precision, flow, and breath. ${ }^{1}$ According to Pilates, his method is total coordination of body, mind, and spirit, promoting the uniform development of the body; restoration of good posture and physical activity; and revitalization of the mind and spirit. ${ }^{2}$ The Pilates method of exercise (PME) is practiced on a mat or Pilates apparatus (body conditioning equipment) in private lessons or small groups. Instructors are certified in the PME through any number of recognized Pilates certification programs.

Initially, the PME found great acceptance among professional dancers. ${ }^{3}$ Today, the PME is popular in the general population $^{1,4,5}$ and the clinical and fitness areas. ${ }^{3,5,6}$ This proliferation has led health and fitness professionals to question the scientific validity of the benefits espoused by Pilates himself. Bernardo ${ }^{4}$ and Bernardo and $\mathrm{Nagle}^{7}$ conducted critical appraisals of the published research in which the PME was tested in healthy adults and dancers, respectively. Their appraisals found weak support for the effectiveness of the PME on outcomes such as strength, flexibility, and alignment because of the quality of research methods and small sample sizes. A similar appraisal of the PME in healthy adults and dancers was conducted by Shedden and Kravitz, ${ }^{8}$ who reinforced the necessity of well-controlled and well-designed studies to scientifically validate the effects of the PME in these populations.

Three systematic reviews ${ }^{6,9,10}$ have been published on the effectiveness of the PME in relieving pain and improving function in adults with low back pain. La Touche et $\mathrm{al}^{6}$ concluded that when adapted for subjects' situations, the PME improved general functioning and decreased pain. Conversely, Lim et $\mathrm{al}^{9}$ found that although the PME is superior to minimal intervention, it is no more effective than other forms of exercise to reduce pain and disability. Posadzki et $\mathrm{al}^{10}$ reported inconclusive evidence to support the clinical effectiveness of the PME in reducing pain and functional disability.

We conducted a systematic review to update the state of the science on effects of the PME in healthy people. The purpose of this systematic review was to answer the question: What is the evidence for the effectiveness of the PME in healthy people?

List of Abbreviations

$\begin{array}{ll}\text { BES } & \text { best evidence synthesis } \\ \text { PEDro } & \text { Physiotherapy Evidence Database } \\ \text { PME } & \text { Pilates method of exercise } \\ \text { RCT } & \text { randomized controlled trial }\end{array}$




\section{METHODS}

\section{Search Strategy}

Studies were selected for review on May 7, 2011, by searching the following databases: Science Direct, MEDLINE Cambridge (1997 to present), PubMed (1950 to present), MEDLINE EBSCOhost (1965 to present), MEDLINE (1950 to present), MEDLINE ISI Web of Knowledge (1950 to present), PEDro (1929 to present), Cochrane Central Register of Controlled Trials, SPORTDiscus (1800 to present), CINAHL (1937 to present), and Web of Science (1900 to present). The search term was Pilates, as found in the title or abstract.

\section{Selection Criteria}

Studies were included if they were published in a peerreviewed journal, written in the English language, conducted as a randomized controlled trial (RCT) or quasi-RCT in healthy people, had an inactive control group and/or exercise control group(s), included key study outcomes (primary measures of the effectiveness or lack of effectiveness of the PME), and used the PME as the study intervention in at least 1 study arm.

\section{Study Selection}

Two reviewers (A.C.-F., L.L.) independently read all abstracts and classified them as excluded or potentially included. A third reviewer (J.F.) was consulted if there was disagreement between the 2 reviewers. Reviewers applied the inclusion criteria after reading the potentially included studies.

\section{Data Extraction}

Studies meeting the inclusion criteria were analyzed independently by the 2 reviewers to extract the following data: authors, year of publication, study design, subjects, intervention used, and key outcomes results. The third reviewer was consulted to resolve disagreements between the 2 reviewers.

\section{Method Quality Assessment}

The 2 reviewers independently assessed the method quality of each RCT by using the Physiotherapy Evidence Database (PEDro) scale, ${ }^{11}$ with the third reviewer consulted to resolve disagreements. All RCTs were scored and entered into a spreadsheet (table 1).

The PEDro scale is based on a Delphi list developed by Verhagen et $\mathrm{al}^{28}$ that includes 11 items: specified eligibility criteria, random allocation, concealed allocation, baseline comparability, blinded subjects, blinded therapists, blinded assessors, adequate follow-up, intention-to-treat analysis, betweengroup comparisons, and point estimates and variability. The eligibility criterion is related to external validity and is not used to calculate the PEDro score. PEDro scale scores range from 1 to 10; higher PEDro scores correspond to higher method quality. Because we do not know of the published validated cutoff scores for the PEDro scale, the following criteria were used to rate method quality: PEDro score of less than 5 indicates low quality and PEDro score of 5 or higher indicates high quality. The reliability of the PEDro scale has been evaluated previously and found sufficient for use in a systematic review of physical therapy $\mathrm{RCTs}^{29}$ and appears to be a useful scale to assess the method quality of physical therapy trials. ${ }^{30}$

\section{Data Synthesis}

RCTs were divided into 2 groups, in which the PME group was compared with an inactive/usual exercise group or another exercise method. Outcomes were categorized as physiologic functioning, psychological functioning, and motor learning. ${ }^{3}$

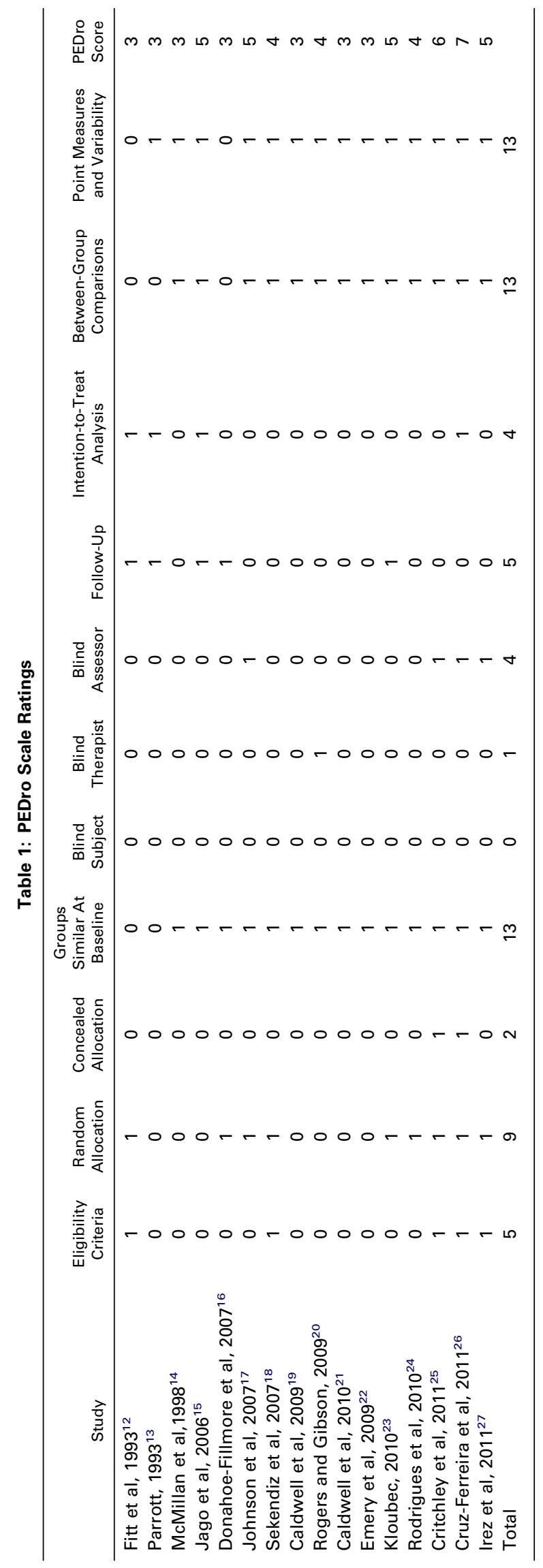


The strength of the scientific evidence was measured by using the best evidence synthesis (BES). BES is an alternative to meta-analysis when the number of eligible studies is too small to establish adequate power. BES has been used successfully by other reviewers, ${ }^{31-34}$ including the Cochrane Back Review Group. ${ }^{35}$ The strength is determined by the number and quality of studies and consistency of results. In this method, quality is more important than quantity. ${ }^{35}$

The following criteria are used to grade the strength of the evidence: strong evidence, provided in multiple high-quality RCTs; moderate evidence, provided in 1 high-quality RCT and 1 or more low-quality RCT; limited evidence, provided in 1 high-quality or multiple low-quality RCTs; and no evidence, provided in 1 low-quality RCT or contradictory outcomes. ${ }^{36}$

\section{RESULTS}

\section{Study Selection}

Figure 1 shows the flowchart of the article selection process. Thirty-one published reports were selected as potentially included for this review. Based on the reviewers' decisions, 16 RCTs matched the inclusion criteria. Seven articles were identified from the Science Direct database, with the remaining articles from MEDLINE $(n=1)$, PubMed $(n=3)$, Sportdiscus $(n=3)$, CINAHL $(n=1)$, and Web of Science $(n=1)$.

\section{Method Quality}

PEDro scale scores ranged from 3 to 7 (mean, 4.1; median, 4; mode, 3). Most studies $(\mathrm{n}=10)$ scored less than 5, 12-14,16,18-22,24 and the rest $(n=6)$ scored 5 or higher, ${ }^{15,17,23,25-27}$ indicating a low and high quality of rigor, respectively. These 6 studies were published within the past 5 years (see table 1 ). The criteria satisfied most often related to statistical issues, such as the "similarity of the groups at baseline are reported for at least 1 key outcome," "results of between-group statistical comparisons are reported for at least 1 key outcome," and the "study provides both point measures and measures of variability for at least 1 key outcome." The criterion "blinded subject" was not satisfied in any RCT, with only 1 and 2 studies satisfying the criteria "blinded therapists" and "allocation was concealed," respectively (see table 1 ).

\section{Study Characteristics}

The most frequent study design was pre-post test $(n=13)$, with 3 studies using an additional measurement during the study intervention. ${ }^{19,21,26}$ None of the studies included followup. Sample sizes were small, ranging from 10 to 62, except in the studies by Caldwell et al, ${ }^{19,21}$ in which 98 and 166 subjects were enrolled, respectively. Half $(n=8)$ of the studies were conducted in adults ${ }^{16-18,20,22,23,25,26} ; 3$ in dancers ${ }^{12-14} ; 3$ in students $^{15,19,21}$; and 2 in older adults. ${ }^{24,27}$ Most RCTs enrolled both women and men $(\mathrm{n}=8),{ }^{12,17,19-23,25}$ with 7 studies limited to women ${ }^{13,15} 16,18,24,26,27$ and 1 study that did not specify subject sex. ${ }^{14}$ All studies used the PME as the study intervention. Control groups were inactive in 11 studies. $^{12,14,15,17,18,20,22-24,26,27}$ In the remaining 5 studies, the PME was compared with Taiji quan, ${ }^{19,21}$ GYROKINESIS, ${ }^{21}$ aerobic conditioning, ${ }^{13}$ recreation, ${ }^{19}$ general postural education, ${ }^{16}$ and strength training. ${ }^{25}$ The duration and frequency of PME interventions ranged from 5 to 15 weeks and 1 to 5 times per week, except for the study by Cruz-Ferreira, ${ }^{26}$ which was conducted twice weekly for 6 months. Nine of the Pilates method interventions were performed on the mat, ${ }^{15,16,18-20,23,25-27}$ with the rest performed on the apparatus (reformer, trapeze table, cadillac, wall unit, combo chair; $n=2),{ }^{17,24}$ the mat and apparatus $(n=3),{ }^{12,14,22}$ or not specified $(n=2)^{13,21}($ table 2$)$.

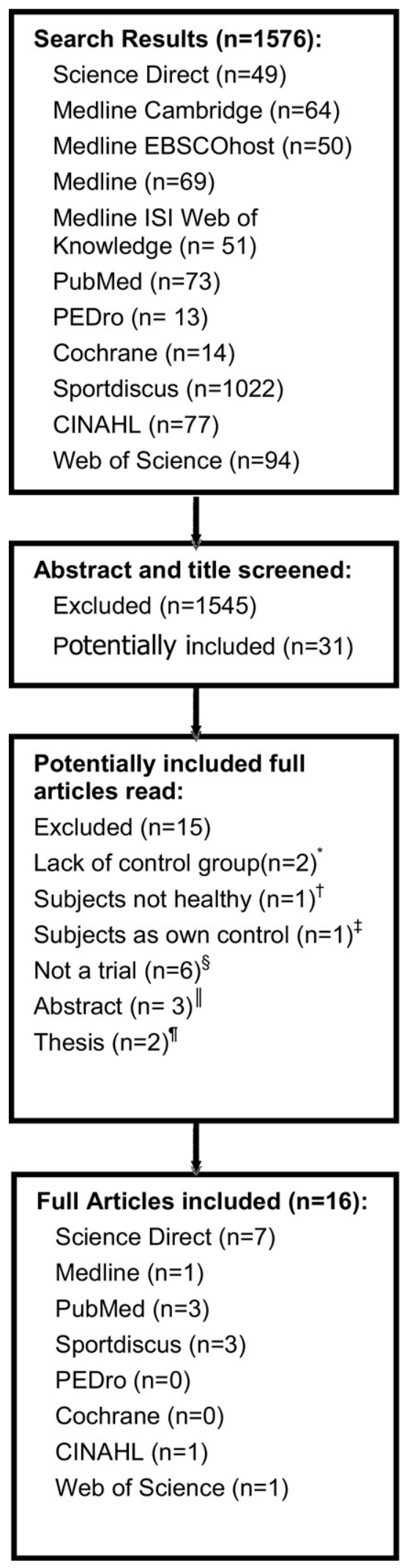

Fig 1. Flowchart of article selection process. ${ }^{*}$ Segal et al, ${ }^{5}$ Kaesler et al..$^{37}$ tCulligan et al. ${ }^{38}$ ₹Kuo et al. ${ }^{39}$ §Menacho et al, ${ }^{40}$ Moreno, ${ }^{41}$ Endleman and Critchley, ${ }^{42}$ Herrington and Davies, ${ }^{43}$ Petrofsky et al, ${ }^{44}$ Queiroz et al ${ }^{45}$ |Sewright et al, ${ }^{46}$ Otto et $\mathrm{al}^{47} \mathrm{Wu}$ and Chiang. ${ }^{48}$ तHall, ${ }^{49} \mathrm{Kish}^{50}$ 


\begin{tabular}{|c|c|c|c|c|}
\hline Study & Design & Subjects & Intervention & Key Outcomes Results \\
\hline Fitt et al, $1993^{12}$ & $\begin{array}{l}\text { Pre-post test } \\
\text { Intervention period } \\
\text { (phase I and } \\
\text { phase II) }\end{array}$ & $\begin{array}{l}\text { University dance students } \\
\text { Phase I } \\
N=29 \text {; mean age, } 21.21 \\
\text { Pilates group: } n=14 \\
\text { Control group 1: } n=15 \\
\text { Phase II } \\
\text { Control group 2: } n=8 \text { (from Phase I } \\
\text { control group 1) }\end{array}$ & $\begin{array}{l}\text { Phase I } \\
\text { Duration: } 7 w k \\
\text { Pilates group and control group } 1=\text { habitual dance } \\
\text { training (technique classes, rehearsals, and } \\
\text { normal conditioning). } \\
\text { Pilates group = habitual dance training and } \\
\text { supervised Pilates session on mat ( } 1 \times 90^{\prime} \text { per } \\
\text { week) and individual work out on apparatus }(2 \times \\
30^{\prime} \text { per week) and daily individual work out } \\
\text { Pilates on mat. } \\
\text { Phase II } \\
\text { Duration: } 5 \text { wk } \\
\text { Control Ggoup } 2=\text { unsupervised Pilates on mat } \\
\text { and supervised Pilates on apparatus. }\end{array}$ & $\begin{array}{l}\text { Phase I } \\
\text { Pilates group = improved upper- and } \\
\text { lower-limb strength, range of motion, } \\
\text { and pelvic alignment; no differences on } \\
\text { vertical jump. } \\
\text { Control group } 1 \text { = no differences on most } \\
\text { of the variables, improved on } 2 \text { strength } \\
\text { variables, } 1 \text { range of motion variable and } \\
\text { decreased on pelvic alignment. } \\
\text { Phase II } \\
\text { Control group } 2 \text { = improved strength, } \\
\text { pelvic alignment, and } 2 \text { range of motion } \\
\text { variables; no differences on vertical jump } \\
\text { and } 2 \text { range of motion variables. }\end{array}$ \\
\hline Parrott, $1993^{13}$ & Pre-post test & $\begin{array}{l}\text { Female university dance students } \\
N=18 ; \text { age range, } 9-30 \\
\text { Pilates group: } n=6 \\
\text { Aerobic conditioning group: } \mathrm{n}=6 \\
\text { Control group: } \mathrm{n}=6\end{array}$ & $\begin{array}{l}\text { Duration: } 14 \mathrm{wk} \\
\text { Pilates group, aerobic conditioning group, and } \\
\text { control group }=\text { dance training }(2-4 \mathrm{~h} \times 4 \text { per } \\
\text { week of rehearsal and } 3-4 \mathrm{~h} \times 5 \text { times per week } \\
\text { of technique class - ballet, modern, and possibly } \\
\text { jazz). } \\
\text { Pilates group }=\text { dance training and Pilates class } \\
\left(3 \times 80^{\prime} \text { per week). }\right. \\
\text { Aerobic conditioning group }=\text { dance training and } \\
\text { aerobic dance class }\left(3 \times 80^{\prime} \text { per week). }\right.\end{array}$ & $\begin{array}{l}\text { Pilates group = improved standing and in- } \\
\text { motion alignment, intention of } \\
\text { movement and expressivity of the body. } \\
\text { Aerobic conditioning group = improved the } \\
\text { expressivity of the body. } \\
\text { Control group = no differences. }\end{array}$ \\
\hline $\begin{array}{l}\text { McMillan et } \\
\text { al,1998 } 14\end{array}$ & Pre-post test & $\begin{array}{l}\text { Ballet dancers } \\
N=10 ; \text { age range, } 15-19 \\
\text { Pilates group: } n=5 \\
\text { Control group: } n=5\end{array}$ & $\begin{array}{l}\text { Duration: } 14 \mathrm{wk} \\
\text { Pilates group = ballet training }(20-25 \mathrm{~h} / \mathrm{wk}) \text { and } 23 \\
\quad \text { private Pilates sessions }(1 \mathrm{~h} \text { each). } \\
\text { Pilates sessions on mat and apparatus. } \\
\text { Control group = ballet training }(20-25 \mathrm{~h} / \mathrm{wk}) .\end{array}$ & $\begin{array}{l}\text { Pilates group = improved the dynamic } \\
\text { alignment of the upper body region. } \\
\text { Control group = no differences. }\end{array}$ \\
\hline $\begin{array}{l}\text { Jago et al, } \\
2006^{15}\end{array}$ & Pre-post test & $\begin{array}{l}\text { Female students } \\
N=30 ; \text { mean age, } 11.2 \\
\text { Pilates group: } n=16 \\
\text { Control group: } n=14\end{array}$ & $\begin{array}{l}\text { Duration and frequency: } 4 w k, 5 \times 60^{\prime} \text { per week. } \\
\text { Pilates group }=\text { Pilates on mat. } \\
\text { Control group }=\text { habitual exercise. }\end{array}$ & $\begin{array}{l}\text { Pilates group }=\text { decreased body mass } \\
\text { index percentile; no differences on body } \\
\text { mass index, waist circumference, and } \\
\text { blood pressure. } \\
\text { Control group = no differences. }\end{array}$ \\
\hline $\begin{array}{l}\text { Donahoe- } \\
\text { Fillmore et al, } \\
2007^{16}\end{array}$ & Pre-post test & $\begin{array}{l}\text { Healthy females } \\
N=11 ; \text { age range, } 25-35 \\
\text { Pilates group: } n=6 \\
\text { Control group: } n=5\end{array}$ & $\begin{array}{l}\text { Duration and frequency: } 10 \mathrm{wk} \\
\text { Pilates group = general postural education ( } 2 \text { per } \\
\text { week) and unsupervised Pilates on mat ( } 3 \text { per } \\
\text { week). } \\
\text { Control group = general postural education ( } 2 \text { per } \\
\text { week). }\end{array}$ & $\begin{array}{l}\text { Pilates group }=\text { improved flexor and } \\
\text { extensor trunk endurance; no differences } \\
\text { on abdominal strength and pelvic } \\
\text { alignment. } \\
\text { Control group = no differences. }\end{array}$ \\
\hline $\begin{array}{l}\text { Johnson et al, } \\
2007^{17}\end{array}$ & Pre-post test & $\begin{array}{l}\text { Healthy adults } \\
N=34 \\
\text { Pilates group: } n=17 \text {; mean age, } 27.5 \\
\text { Control group: } n=17 \text {; mean age, } 27.3\end{array}$ & $\begin{array}{l}\text { Duration: } 10 \text { sessions within } 5 w k \\
\text { Pilates group }=\text { Pilates on apparatus. } \\
\text { Control group }=\text { no exercise. }\end{array}$ & $\begin{array}{l}\text { Pilates group }=\text { improved dynamic } \\
\text { standing balance. } \\
\text { Control group }=\text { no differences. }\end{array}$ \\
\hline
\end{tabular}

$\mathrm{N}=29$; mean age, 21.21

Phase II

ontrol group 2: $n=8$ (from Phase I control group 1)

ance students $\mathrm{N}=18$; age range, $9-30$

Control group: $n=6$

$\mathrm{N}=10$; age range, $15-19$

Pilates group: $n=5$

Control group: $n=5$

Pilates group: $\mathrm{n}=16$

Healthy females

$\mathrm{N}=11$; age range, $25-35$

Pilates group: $n=6$

Healthy adults

Pilates group: $\mathrm{n}=17$; mean age, 27.5

Control group: $n=17$; mean age, 27.3 lates group and control group $1=$ habitual dance

supervised Pilates session on mat $\left(1 \times 90^{\prime}\right.$ per

Duration: $5 w$

ation: $14 \mathrm{wk}$

jazz).

aerobic dance class $\left(3 \times 80^{\prime}\right.$ per week).

Pilates group $=$ ballet training $(20-25 \mathrm{~h} / \mathrm{wk})$ and 23

private Pilates sessions ( $1 \mathrm{~h}$ each).

Pilates sessions on mat and apparatus.

Pilates group $=$ Pilates on mat.

Duration and frequency: 10wk

Pilates group $=$ general postural education $(2$ per

week) and unsupervised Pilates on mat (3 per

Duration: 10 sessions within $5 \mathrm{wk}$

Piles group $=$ Pilates on apparatus.

group $=$ no exercise 
Table 2 (Cont'd): Description of Studies Included in RCT

\begin{tabular}{|c|c|c|c|c|}
\hline Study & Design & Subjects & Intervention & Key Outcomes Results \\
\hline $\begin{array}{l}\text { Sekendiz et al, } \\
2007^{18}\end{array}$ & Pre-post test & $\begin{array}{l}\text { Sedentary adult females } \\
N=38 \\
\text { Pilates group: } n=21 \text {; mean age, } 30 \\
\text { Control group: } n=17 ; \text { mean age, } 30\end{array}$ & $\begin{array}{l}\text { Duration and frequency: } 5 \mathrm{wk}, 3 \times 60^{\prime} \text { per week. } \\
\text { Pilates group }=\text { Pilates on mat } \\
\text { Control group }=\text { no exercise. }\end{array}$ & $\begin{array}{l}\text { Pilates group }=\text { increased abdominal and } \\
\text { lower back strength, abdominal muscular } \\
\text { endurance, and posterior trunk flexibility. } \\
\text { Control group }=\text { no differences. }\end{array}$ \\
\hline $\begin{array}{l}\text { Caldwell et al, } \\
2009^{19}\end{array}$ & $\begin{array}{l}\text { Pre, mid, and post } \\
\text { test }\end{array}$ & $\begin{array}{l}\text { College-age individuals } \\
\mathrm{N}=98 \\
\text { Pilates group: } \mathrm{n}=41 \\
\text { Taiji quan group: } \mathrm{n}=29 \\
\text { Recreation group: } \mathrm{n}=28 \\
\text { Mean age, } 21.27\end{array}$ & $\begin{array}{l}\text { Duration: } 15 \mathrm{wk} \text {. } \\
\text { Pilates group }=2 \times 75^{\prime} \text { per week or } 3 \times 50^{\prime} \text { per } \\
\text { week. } \\
\text { Supervised Pilates sessions on mat. } \\
\text { Taiji quan group }=2 \times 50^{\prime} \text { per week Taiji quan } \\
\text { sessions. } \\
\text { Recreation group }=\text { habitual exercise. }\end{array}$ & $\begin{array}{l}\text { Pilates group = improved self-efficacy, } \\
\text { positive mood, and sleep quality. } \\
\text { Taiji quan = no differences. } \\
\text { Recreation group = no differences. }\end{array}$ \\
\hline $\begin{array}{l}\text { Rogers and } \\
\text { Gibson, } \\
2009^{20}\end{array}$ & Pre-post test. & $\begin{array}{l}\text { Healthy adults } \\
\mathrm{N}=22 \\
\text { Pilates group: } \mathrm{n}=9 \text {; mean age, } 25.5 \\
\text { Control group: } \mathrm{n}=13 \text {; mean age, } 24.5\end{array}$ & $\begin{array}{l}\text { Duration and frequency: } 8 \text { wk, } 3 \times 60^{\prime} \text { per week. } \\
\text { Pilates group }=\text { supervised Pilates sessions } \\
\text { program on mat. } \\
\text { Control group = habitual unsupervised, self- } \\
\text { prescribed cardiovascular and strength training } \\
\text { regimens. }\end{array}$ & $\begin{array}{l}\text { Exercise group = improved body } \\
\text { composition (body density, relative body } \\
\text { fat, chest, waist, and arm circumference), } \\
\text { flexibility (low back, hamstrings, and } \\
\text { upper body), and muscular endurance } \\
\text { (abdominal and lower back); no } \\
\text { differences on hips and thigh } \\
\text { circumference. Control group = no } \\
\text { differences. }\end{array}$ \\
\hline $\begin{array}{l}\text { Caldwell et al, } \\
2010^{21}\end{array}$ & $\begin{array}{l}\text { Pre, mid, and post } \\
\text { test }\end{array}$ & $\begin{array}{l}\text { College students } \\
\mathrm{N}=166 \\
\text { Pilates group: } \mathrm{n}=80 \\
\text { GYROKINESIS group: } \mathrm{n}=48 \\
\text { Taiji quan group: } \mathrm{n}=38\end{array}$ & $\begin{array}{l}\text { Duration: } 15 \mathrm{wk} \\
\text { Pilates group and GYROKINESIS group }=2 \times 75^{\prime} \text { or } \\
3 \times 50^{\prime} \text { per week. } \\
\text { Taiji quan group }=2 \times 50^{\prime} \text { per week. }\end{array}$ & $\begin{array}{l}\text { Pilates, GYROKINESIS, and Taiji quan } \\
\text { group = improved overall mindfulness. } \\
\text { These increases were related with } \\
\text { improved sleep quality, self-regulatory, } \\
\text { self-efficacy, mood, and perception of } \\
\text { stress. }\end{array}$ \\
\hline $\begin{array}{l}\text { Emery et al, } \\
2009^{22}\end{array}$ & Pre-post test & $\begin{array}{l}\text { Healthy adults } \\
\mathrm{N}=19 \\
\text { Pilates group: } \mathrm{n}=10 ; \text { mean age, } 31.1 \\
\text { Control group: } \mathrm{n}=9 \text {; mean age, } 28.6\end{array}$ & $\begin{array}{l}\text { Duration and frequency: } 12 \mathrm{wk}, 2 \times 60^{\prime} \text { per week. } \\
\text { Pilates group = private Pilates sessions on mat and } \\
\text { apparatus. } \\
\text { Control group }=\text { no exercise. }\end{array}$ & $\begin{array}{l}\text { Pilates group = improved abdominal } \\
\text { strength, thoracic kyphosis, and } \\
\text { stabilization of core posture during } \\
\text { shoulder flexion task movements. } \\
\text { Control group = no differences. }\end{array}$ \\
\hline Koulbec $2010^{23}$ & Pre-post test & $\begin{array}{l}\text { Healthy active middle age } \\
N=50 ; \text { age range, } 25-65 \\
\text { Pilates group: } n=25 \\
\text { Control group: } n=25\end{array}$ & $\begin{array}{l}\text { Duration: } 12 \mathrm{wk} . \\
\text { Pilates group }=2 \times 60^{\prime} \text { per week. } \\
\text { Supervised Pilates classes on mat. } \\
\text { Control group }=\text { no exercise. }\end{array}$ & $\begin{array}{l}\text { Pilates group = improved abdominal and } \\
\text { upper body endurance and hamstring } \\
\text { flexibility; no differences on static } \\
\text { balance and posture. } \\
\text { Control group = no differences. }\end{array}$ \\
\hline $\begin{array}{l}\text { Rodrigues et al, } \\
2010^{24}\end{array}$ & Pre-post test & $\begin{array}{l}\text { Elderly females } \\
\mathrm{N}=52 ; \text { mean age, } 66 \\
\text { Pilates group: } \mathrm{n}=27 \\
\text { Control group: } \mathrm{n}=25\end{array}$ & $\begin{array}{l}\text { Duration and frequency: } 8 w k, 2 \times 60^{\prime} \text { per week. } \\
\text { Pilates group }=\text { supervised Pilates on apparatus. } \\
\text { Control group }=\text { no exercise. }\end{array}$ & $\begin{array}{l}\text { Pilates group }=\text { improved the static } \\
\text { balance, personal autonomy and quality } \\
\text { of life index. } \\
\text { Control group = no differences. }\end{array}$ \\
\hline
\end{tabular}




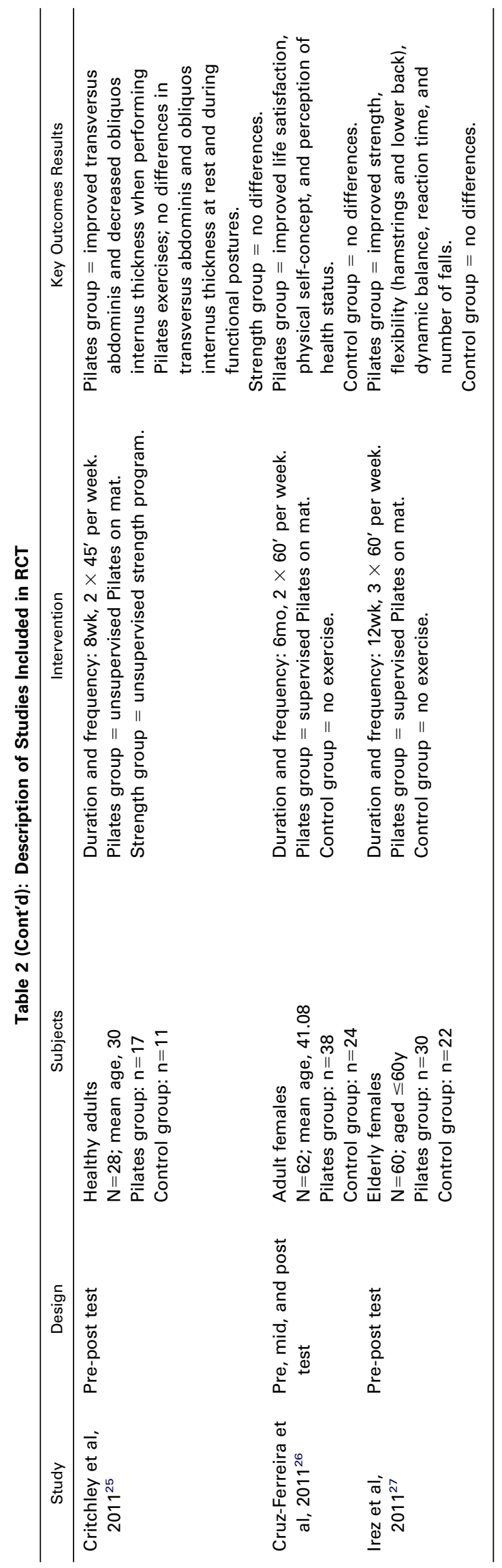

\section{Effects of the PME on Health Outcomes}

In physiologic functioning, improvements were reported in flexibility, ${ }^{18,20,23,27}$ muscular endurance, ${ }^{16,18,20,23}$ transversus abdominis thickness, ${ }^{25}$ range of motion, ${ }^{12}$ strength, ${ }^{12,18,22,27}$ reaction time, number of falls, ${ }^{27}$ and body composition. ${ }^{15,20}$ No improvements were reported in transversus abdominis and obliquus internus thickness at rest or during functional postures, ${ }^{25}$ blood pressure, ${ }^{15}$ abdominal strength, ${ }^{16}$ body composition, ${ }^{15,20}$ and vertical jump. ${ }^{12}$ In psychological functioning, improvements were found in intention of movement, expressivity of the body, ${ }^{13}$ self-efficacy, positive mood and sleep quality, ${ }^{19}$ mindfulness, ${ }^{21}$ personal autonomy, quality-of-life index, ${ }^{24}$ life satisfaction, physical self-concept, and perception of health status. ${ }^{26}$ In motor learning, enhancements were observed in dynamic balance, ${ }^{17,27}$ static balance, ${ }^{24}$ stabilization of core posture, ${ }^{22}$ and postural alignment. ${ }^{12-14,22}$ No enhancements were found in postural alignment $^{16,23}$ or static balance. ${ }^{23}$ Overall, the outcomes studied most often were flexibility, ${ }^{18,20,23,27}$ muscular endurance, ${ }^{16,18,20,23}$ strength, ${ }^{12,16,18,22,27}$ and postural alignment ${ }^{12-14,16,22,23}$ (see table 2).

\section{Strength of the Evidence Using the BES Grading System}

Applying the BES to measure the strength of the evidence, strong evidence was found for improving flexibility (physiologic functioning category) 18,20,23,27 and dynamic balance (motor learning category). ${ }^{17,27}$ Moderate evidence was found for improving muscular endurance (physiologic functioning category). ${ }^{16,18,20,23}$ Limited and no evidence was found for the rest of the outcomes. Table 3 lists the strength of the evidence of each outcome and the direction of the effect against a comparison group. Figure 2 shows the number of outcomes in each level of the strength of evidence. Contradictory results were found in a number of studies and are listed in table 4.

\section{DISCUSSION}

This systematic review was conducted to answer the question: What is the evidence for the effectiveness of the PME on outcomes in healthy people? This investigation adds to previous reviews by applying a method quality scale, evaluating the strength of evidence by using an established grading system, and including a larger number of published RCTs. We found strong evidence to support the use of the PME to improve flexibility and dynamic balance, moderate evidence to improve muscular endurance, and limited evidence to improve transversus abdominis and to decrease obliquus internus thickness during performance of the PME, and to improve reaction of time, number of falls, life satisfaction, physical self-concept, and perception of health status. Limited evidence was found, with no change in transversus abdominis and obliquus internus thickness while at rest or during functional postures. No evidence was found for the rest of the outcomes.

Until the mid-1980s, the PME was known and practiced almost exclusively by dancers. By the 1990s, this method had increased in popularity outside the world of dance. ${ }^{1}$ This historical timeline helps explain why the first 3 RCTs, published in the 1990 s, were conducted with dancers. Since 2000 , with the proliferation of the PME into mainstream fitness and exercise, an increasing number of published RCTs using the PME in healthy people have been published. More than half $(n=9)$ the published studies were performed on the mat compared with the apparatus and mat plus apparatus. This is not surprising because mat exercises are not as demanding in terms of supervision, are more affordable and readily available, and can be taught in larger groups 
Table 3: Levels of Evidence of Outcomes in Physiologic, Psychological, and Motor Learning Categories

\begin{tabular}{|c|c|c|c|}
\hline & Level of Evidence & Outcome & Study Arms \\
\hline \multirow{6}{*}{$\begin{array}{l}\text { Physiologic } \\
\text { Functioning } \\
\text { Category }\end{array}$} & Strong evidence & Flexibility + & Compared with inactive control or habitual \\
\hline & Moderate evidence & Muscular endurance + & exercise groups. \\
\hline & Limited evidence & $\begin{array}{l}\text { Transversus abdominis thickness when } \\
\text { performing Pilates exercises }+ \\
\text { Transversus abdominis and obliquos } \\
\text { internus thickness at rest and during } \\
\text { functional postures - }\end{array}$ & Compared with strength group. \\
\hline & & $\begin{array}{l}\text { Reaction time }+ \\
\text { Number of falls }+\end{array}$ & Compared with inactive control group. \\
\hline & No evidence & $\begin{array}{l}\text { Range of motion }+ \\
\text { Strength }+-\end{array}$ & $\begin{array}{l}\text { Compared with habitual exercise group. } \\
\text { Compared with inactive control or habitual exercise } \\
\text { group or general postural education group. }\end{array}$ \\
\hline & & $\begin{array}{l}\text { Body composition }+- \\
\text { Vertical jump - }\end{array}$ & Compared with habitual exercise group. \\
\hline \multirow{6}{*}{$\begin{array}{l}\text { Psychological } \\
\text { Functioning } \\
\text { Category }\end{array}$} & Limited evidence & Life satisfaction + & \\
\hline & & $\begin{array}{l}\text { Physical self-concept }+ \\
\text { Perception of health status }+\end{array}$ & Compared with inactive control group. \\
\hline & No evidence & $\begin{array}{l}\text { Intention of movement }+ \\
\text { Expressivity the body }+ \\
\text { Self efficacy }+\end{array}$ & $\begin{array}{l}\text { Compared with aerobic conditioning and inactive } \\
\text { control groups. }\end{array}$ \\
\hline & & $\begin{array}{l}\text { Positive mood }+ \\
\text { Sleep quality }+\end{array}$ & Compared with Taiji quan and habitual exercise groups. \\
\hline & & Mindfulness + & Compared with Taiji quan and Gyrokinesis groups. \\
\hline & & $\begin{array}{l}\text { Personal autonomy }+ \\
\text { Quality of life index }+\end{array}$ & Compared with inactive control group. \\
\hline \multirow[t]{3}{*}{$\begin{array}{l}\text { Motor Learning } \\
\text { Category }\end{array}$} & Strong evidence & $\begin{array}{l}\text { Dynamic balance }+ \\
\text { Stabilization of core posture }+\end{array}$ & Compared with inactive control group. \\
\hline & No evidence & Postural alignment +- & $\begin{array}{l}\text { Compared with inactive control or habitual exercise } \\
\text { groups or general postural education or inactive } \\
\text { control group and aerobic conditioning groups or }\end{array}$ \\
\hline & & Static balance +- & Compared with inactive control groups. \\
\hline
\end{tabular}

Abbreviations: + , positive results;,- no changes; +- , contradictory results.

compared with apparatus exercises. There were no published studies comparing the type of Pilates training (mat or apparatus) and the type of Pilates certification method and its impact on outcomes.

The method quality of studies generally was low (mean score, 4.1). PEDro scale items satisfied most often in the 16 RCTs are related to the similarity of subject characteristics at baseline, between-group comparisons, and point measures and variability. These items indicate strengths in the subject enrollment process and in analyzing subjects' data by using meaningful measures and statistical analyses. Although all studies were reported as RCTs, 9 did not satisfy the randomization criteria because they did not explicitly state that allocation was random. Items less satisfied were criteria related to blinding (blinding of therapist and subjects) and random allocation. Blinding of subjects ${ }^{31,51}$ and therapists ${ }^{31}$ is difficult to achieve in exercise studies. The intention-to-treat criterion was satisfied in only 4 studies. This criterion is important when determining a study's power to detect differences between groups and can be a threat to external validity. Intention to treat also encompasses subject dropouts, and less than one-third of the studies had a dropout rate less than $15 \%$. Exercise studies with control groups can be plagued with high dropout rates because of subject disinterest, and methods to retain randomly assigned subjects should be used.

Strong evidence was found for the PME improving flexibility compared with inactive $\mathrm{i}^{18,23,27}$ or habitual exercise groups ${ }^{20}$ and dynamic balance compared with inactive groups. ${ }^{17,27}$ This evidence was provided by 2 high-quality RCTs for each outcome.

Moderate evidence was observed for improving muscular endurance compared with inactive ${ }^{18,23}$ or habitual exercise ${ }^{20}$ or general postural education groups, ${ }^{16}$ provided by 1 high-quality and 3 low-quality RCTs. Additionally, changes in muscular endurance were not observed in general postural education groups, which determines the superiority of PME enhancing this outcome.

Limited evidence was found in improving transversus abdominis and decreasing obliquos internus thickness of adults during performance of the PME by comparing the PME and strength training. ${ }^{25}$ Neither group improved this outcome while at rest or during functional postures. Therefore, although the PME increased muscle mass, it did not improve function compared with strength training alone. Furthermore, limited evidence was found for improving reaction time, number of falls, ${ }^{27}$ life satisfaction, physical self-concept, and perception of health status ${ }^{26}$ when the PME was compared with an inactive control group. ${ }^{26,27}$ These conclusions were drawn from 1 RCT with a high methodological quality.

There was no evidence for range of motion and vertical jump compared with a habitual exercise group. ${ }^{12}$ No evidence was found for most outcomes of the psychological category. Women dance students who enrolled in Pilates method 

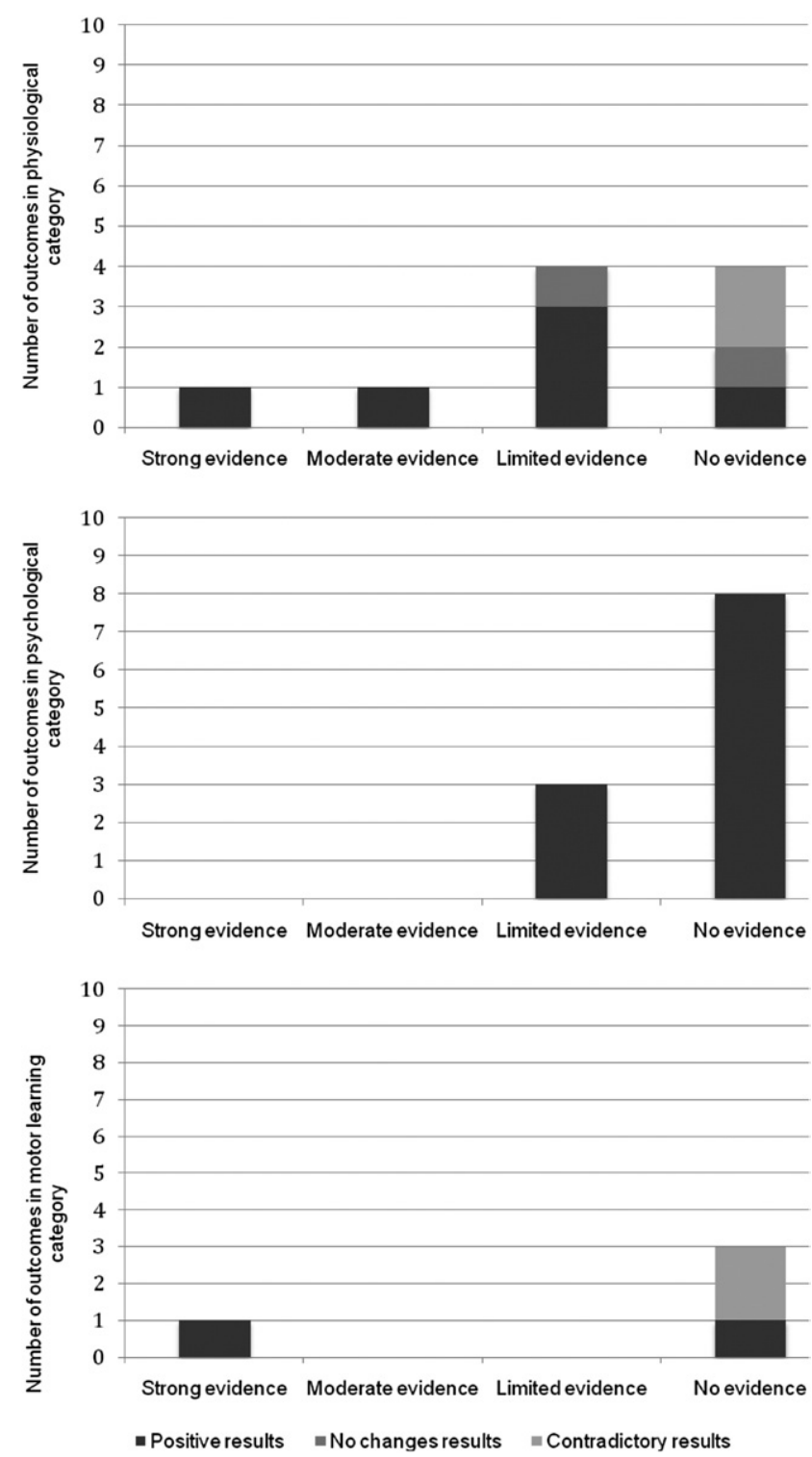

Fig 2. Number of outcomes in each level of strength evidence.

classes enhanced their intention of movement and expressivity of the body. ${ }^{13}$ Although the control group had no differences, the aerobic conditioning group improved only expressivity of the body, which does not establish the superiority of the PME in this outcome. Similar conclusions were presented by Caldwell et al, ${ }^{21}$ in which mindfulness was reported in college students after practicing the PME, GYROKINESIS, and Taiji quan programs. All these interventions are mind-body fitness methods; therefore, variability among groups was expected to be minimal. In contrast, Caldwell et al ${ }^{19}$ showed that the PME promoted self-efficacy, positive mood, and sleep quality, making this method a better choice than Taiji quan and recreation. These health outcomes are psychological in nature, and the physicality of the PME may contribute to the improved outcomes in this study.

No evidence was found for outcomes with contradictory results, which calls into question the effectiveness of the PME in outcomes in the physiologic (body composition and strength) and motor learning (postural alignment, static balance) categories (see table 4). Contradictory results were found for abdominal strength, for which improvements were observed by Sekendiz, ${ }^{18}$ Emery, ${ }^{22}$ and colleagues and no improvements were found by Donahoe-Fillmore et al. ${ }^{16}$ Differences between Sekendiz, ${ }^{18}$ Donahoe-Fillmore, ${ }^{16}$ and colleagues may be related to the process for measuring abdominal strength (maximum curl-ups vs isometric contraction, respectively). Contradictions with conclusions drawn by Emery, ${ }^{22}$ Donahoe-Fillmore, ${ }^{16}$ and colleagues may be due to the instructional and Pilates equipment methods (private Pilates method on the mat and apparatus vs unsupervised Pilates method on the mat, respectively) and duration of the Pilates method intervention $(12 \mathrm{vs} 10 \mathrm{wk}$, respectively). In the study by Jago et al, ${ }^{15}$ no differences were found in women students' waist circumferences after 4 weeks of practicing the PME on the mat. Alternatively, Rogers and Gibson ${ }^{20}$ found improvements in waist circumference after 8 weeks of practicing the PME. Knowing that the procedure for waist measurement was the same for both studies, the difference in waist measurements may be because of the duration of the intervention, for which 4 weeks was not sufficient to produce decreases in waist circumference. Donahoe-Fillmore, ${ }^{16}$ Fitt, ${ }^{12}$ and colleagues assessed pelvic postural alignment by using the same procedures. In the first study, 10 weeks of general postural education and unsupervised Pilates on the mat did not produce effects on pelvic alignment in healthy adult women ${ }^{16}$ compared with the general postural education group. In comparison, dance students, after 7 weeks of habitual dance training, supervised Pilates method on the mat, individual work on the apparatus, and daily individual work with Pilates on the mat, improved pelvic postural alignment. ${ }^{12}$ The dancers' workload and supervised training could explain the differences in findings. Furthermore, dance students have an inherent capacity to internalize and apply the PME in their body work. Benefits were found in static balance in Rodrigues et al's investigation, ${ }^{24}$ whereas Kloubec ${ }^{23}$ did not observe differences. Such differences may be because of the measures devices and type of intervention. Rodrigues ${ }^{24}$ used the Tinetti test, ${ }^{52}$ and the intervention was based on supervised Pilates on the apparatus. Kloubec ${ }^{23}$ used a balance board, and the intervention consisted of supervised Pilates on the mat. Thus, the contradictory findings may be because of differences in surface (stable vs unstable) and equipment (Pilates equipment vs the mat).

The low PEDro scale scores indicated weaknesses in research methods (lack of blinding, intention to treat, concealed allocation), and the lack of strength of evidence calls into question the effectiveness of the PME in healthy people and implies caution when applying the findings into practice. Other factors that affect the scientific validity of the effects include the type of certified PME, veracity of the PME instructor, and variability in measurement, study length, frequency of PME sessions, and age ranges of subjects.

\section{Study Limitations}

There are a number of limitations with our systematic review. We excluded all studies that were not RCTs or were quasi-RCTs. We did not determine the validity and reliability of the instruments, integrity of the type of PME taught, qualifications of Pilates method instructors, or appropriateness of statistical analyses. Outcomes were broadly grouped, and studies used various criteria for measuring outcomes. No study conducted follow-up assessments to determine lasting effects of the PME on outcomes. A meta-analysis of all RCTs was not feasible because of the clinical heterogeneity of study mea- 
Table 4: Outcomes With Contradictory Results in Healthy People

\begin{tabular}{|c|c|c|c|}
\hline & Outcome & Study & Results \\
\hline \multirow[t]{5}{*}{ Strength } & $\begin{array}{l}\text { Upper and lower } \\
\text { limbs }\end{array}$ & Fitt et al, $1993^{12}$ & $\begin{array}{l}\text { Pilates group improved upper- and lower-limb strength when } \\
\text { compared with habitual dance training group. }\end{array}$ \\
\hline & Lower back & Sekendiz et al, $2007^{18}$ & $\begin{array}{l}\text { Pilates group improved lower back strength when compared } \\
\text { with no exercise control group. }\end{array}$ \\
\hline & Hip & Irez, et al, $2011^{27}$ & $\begin{array}{l}\text { Pilates group improved hip strength, when compared with } \\
\text { no exercise control group }\end{array}$ \\
\hline & \multirow[t]{2}{*}{ Abdominal } & $\begin{array}{l}\text { Sekendiz et al, } 2007^{18} \\
\text { Emery et al, } 2010^{22}\end{array}$ & $\begin{array}{l}\text { Pilates group improved abdominal strength when compared } \\
\text { with no exercise control group. }\end{array}$ \\
\hline & & $\begin{array}{l}\text { Donahoe-Fillmore et al, } \\
22007^{16}\end{array}$ & $\begin{array}{l}\text { Pilates group did not improve abdominal strength when } \\
\text { compared with general postural education group. }\end{array}$ \\
\hline \multirow[t]{7}{*}{ Body Composition } & $\begin{array}{l}\text { Body mass index } \\
\text { percentile }\end{array}$ & Jago et al, $2006^{15}$ & $\begin{array}{l}\text { Pilates group improved body mass index percentile when } \\
\text { compared with habitual exercise control group. }\end{array}$ \\
\hline & Body mass index & Jago et al, $2006^{15}$ & $\begin{array}{l}\text { Pilates group did not improve body mass index when } \\
\text { compared with habitual exercise control group. }\end{array}$ \\
\hline & Waist circumference & Jago et al, $2006^{15}$ & $\begin{array}{l}\text { Pilates group did not improve waist circumference when } \\
\text { compared with habitual exercise control group. }\end{array}$ \\
\hline & Body density & $\begin{array}{l}\text { Rogers and Gibson, } \\
2009^{20}\end{array}$ & $\begin{array}{l}\text { Pilates group improved body density when compared with } \\
\text { habitual self-prescribed cardiovascular and strength } \\
\text { training group. }\end{array}$ \\
\hline & Relative body fat & $\begin{array}{l}\text { Rogers and Gibson, } \\
2009^{20}\end{array}$ & $\begin{array}{l}\text { Pilates group improved relative body fat when compared } \\
\text { with habitual self-prescribed cardiovascular and strength } \\
\text { training group. }\end{array}$ \\
\hline & $\begin{array}{l}\text { Chest, waist, and arm } \\
\text { circumference }\end{array}$ & $\begin{array}{l}\text { Rogers and Gibson, } \\
2009^{20}\end{array}$ & $\begin{array}{l}\text { Pilates group improved chest, waist, and arm circumference } \\
\text { when compared with habitual self-prescribed } \\
\text { cardiovascular and strength training group. }\end{array}$ \\
\hline & $\begin{array}{l}\text { Hips and thigh } \\
\text { circumference }\end{array}$ & $\begin{array}{l}\text { Rogers and Gibson, } \\
2009^{20}\end{array}$ & $\begin{array}{l}\text { Pilates group did not improve hips and thigh circumference } \\
\text { when compared with habitual self-prescribed } \\
\text { cardiovascular and strength training group. }\end{array}$ \\
\hline \multirow[t]{2}{*}{ Balance } & \multirow[t]{2}{*}{ Static balance } & $\begin{array}{l}\text { Kloubec, } 2010^{23} \\
\text { Rodrigues et al, } 2010^{24}\end{array}$ & $\begin{array}{l}\text { Pilates did not improve static balance when compared with } \\
\text { no exercise control group. }\end{array}$ \\
\hline & & & $\begin{array}{l}\text { Pilates improve static balance when compared with no } \\
\text { exercise control group }\end{array}$ \\
\hline \multirow[t]{6}{*}{ Postural Alignment } & Pelvic & Fitt et al, $1993^{12}$ & $\begin{array}{l}\text { Pilates group improved pelvic alignment when compared } \\
\text { with habitual dance training group. }\end{array}$ \\
\hline & Pelvic & $\begin{array}{l}\text { Donahoe-Fillmore et al, } \\
2007^{16}\end{array}$ & $\begin{array}{l}\text { Pilates group did not improve pelvic alignment when } \\
\text { compared with no general postural education group. }\end{array}$ \\
\hline & $\begin{array}{l}\text { Standing and in- } \\
\text { motion alignment }\end{array}$ & Parrott, $1993^{13}$ & $\begin{array}{l}\text { Pilates group improved standing and in-motion alignment } \\
\text { when compared with no exercise group and aerobic } \\
\text { conditioning group. }\end{array}$ \\
\hline & Dynamic & McMillan et al, $1998^{14}$ & $\begin{array}{l}\text { Pilates group improved dynamic alignment of upper body } \\
\text { region when compared with habitual dance training group. }\end{array}$ \\
\hline & Thoracic & Emery et al, $2009^{22}$ & $\begin{array}{l}\text { Pilates improved thoracic kyphosis when compared with no } \\
\text { exercise control group. }\end{array}$ \\
\hline & Unspecified & Kloubec, $2010^{23}$ & $\begin{array}{l}\text { Pilates did not improve posture when compared with no } \\
\text { exercise control group. }\end{array}$ \\
\hline
\end{tabular}

sures, small sample sizes, and lack of randomization. PEDro scale scoring comes with it own biases because items were scored only when the study clearly reported that criteria were met. The BES is relatively new in its application; thus, the strength of the evidence may have been over- or underestimated.

\section{Recommendations for Future Research}

The method quality of RCTs involving the PME should be improved to minimize bias, namely, concealing group allocation, using blinding criteria, using power analysis to determine sample size, applying an intention-to-treat analysis, and using interventions to decrease dropout rates. Furthermore, reporting the type of PME, order of exercises, and number of repetitions for each exercise would allow for reproducibility and consistency among researchers. Maintaining consistency in study duration and number and length of PME sessions would enhance the translation research findings into practice.

\section{CONCLUSIONS}

Findings from this systematic review indicate that the PME in healthy people has a low quality of scientific rigor. There was strong evidence to support use of the PME, at least at the end of training, to improve flexibility and dynamic balance and moderate evidence to enhance muscular endurance. Given the 
paucity of published RCTs, lack of follow-up designs, low method quality of most RCTs, and limited strength of the evidence, more rigorous and robust methods should be used in future investigations.

Acknowledgments: We thank Nelson Cortes, $\mathrm{PhD}$, for help in the database and the colleagues of the Department of Sport and Health, University of Évora, for encouragement and support.

\section{References}

1. Latey P. The Pilates method: history and philosophy. J Bodyw Mov Ther 2001;5:275-82.

2. Pilates J, Miller W. Return to life through contrology. Incline Village: Presentation Dynamics; 1945.

3. Lange C, Unnithan V, Larkam E, Latta P. Maximizing the benefits of Pilates-inspired exercise for learning functional motor skills. J Bodyw Mov Ther 2000;4:99-108.

4. Bernardo L. The effectiveness of Pilates training in healthy adults: an appraisal of the research literature. J Bodyw Mov Ther 2007; 11:106-10.

5. Segal NA, Hein J, Basford JR. The effects of Pilates training on flexibility and body composition: an observational study. Arch Phys Med Rehabil 2004;85:1977-81.

6. La Touche R, Escalante K, Linares M. Treating non-specific chronic low back pain through the Pilates method. J Bodyw Mov Ther 2008;12:364-70.

7. Bernardo L, Nagle E. Does Pilates training benefit dancers? An appraisal of Pilates research literature. J Dance Med Sci 2006;10: 46-50.

8. Shedden M, Kravitz L. Pilates exercise: a research-based review. J Dance Med Sci 2006;10:111-6.

9. Lim EC, Poh RL, Low AY, Wong WP. Effects of Pilates-based exercises on pain and disability in persistent nonspecific low back pain: a systematic review with meta-analysis. J Orthop Sports Phys Ther 2011;41:70-80.

10. Posadzki P, Lizis P, Hanger-Derengowska M. Pilates for low back pain: a systematic review. Complement Ther Clin Pract 2011;17: 85-89.

11. de Morton NA. The PEDro scale is a valid measure of the methodological quality of clinical trials: a demographic study. Aust J Physiother 2009;55:129-33.

12. Fitt S, Sturman J, McClain-Smith S. Effects of Pilates-based conditioning on strength, alignment, and range of motion in university ballet and modern dance majors. Kinesiol Med Dance 1993;16:36-51.

13. Parrott A. The effects of Pilates technique and aerobic conditioning on dancers' technique and aesthetic. Kinesiol Med Dance 1993;15:45-64.

14. McMillan A, Proteau L, Lèbe R. The effect of Pilates-based training on dancers' dynamic posture. J Dance Med Sci 1998;2: $101-7$.

15. Jago R, Jonker M, Missaghian M, Baranowski T. Effect of 4 weeks of Pilates on the body composition of young girls. Prev Med 2006;42:177-80.

16. Donahoe-Fillmore B, Hanahan N, Mescher M, Clapp D, Addison $\mathrm{N}$, Weston $\mathrm{C}$. The effects of a home Pilates program on muscle performance and posture in healthy females: a pilot study. J Womens Health Phys Ther 2007;31:6-11.

17. Johnson E, Larsen A, Ozawa H, Wilson C, Kennedy K. The effects of Pilates-based exercise on dynamic balance in healthy adults. J Bodyw Mov Ther 2007;11:238-42.

18. Sekendiz B, Altun O, Korkusuz F, Akın S. Effects of Pilates exercise on trunk strength, endurance and flexibility in sedentary adult females. J Bodyw Mov Ther 2007;11:318-26.

19. Caldwell K, Harrison M, Adams M, Travis Triplett N. Effect of Pilates and Taiji quan training on self-efficacy, sleep quality, mood, and physical performance of college students. J Bodyw Mov Ther 2009;13:155-63.

20. Rogers K, Gibson AL. Eight-week traditional mat Pilates trainingprogram effects on adult fitness characteristics. Res Q Exerc Sport 2009;80:569-74.

21. Caldwell K, Harrison M, Adams M, Quin RH, Greeson J. Developing mindfulness in college students through movement-based courses: effects on self-regulatory self-efficacy, mood, stress, and sleep quality. J Am Coll Health 2010;58:433-42.

22. Emery K, De Serres S, McMillan A, Côté J. The effects of a Pilates training program on arm-trunk posture and movement. Clin Biomech 2009;25:124-30.

23. Kloubec JA. Pilates for improvement of muscle endurance, flexibility, balance, and posture. J Strength Con Res 2010;2:661-7.

24. Rodrigues B, Cader S, Torres N, Oliveira E, Dantas E. Pilates method in personal autonomy, static balance and quality of life. J Bodyw Mov Ther 2010;14:195-202.

25. Critchley DJ, Pierson Z, Battersby G. Effect of Pilates mat exercises and conventional exercise programmes on transversus abdominis and obliquus internus abdominis activity: pilot randomised trial. Man Ther 2011;16:183-9.

26. Cruz-Ferreira A, Fernandes J, Gomes D, et al. Effects of Pilatesbased exercise on life satisfaction, physical self-concept and health status in adult women. Womens Health 2011;51:240-55.

27. Irez GB, Ozdemir RA, Evin R, Irez SG, Korkusuz F. Integrating Pilates exercise into an exercise program for $65+$ year-old women to reduce falls. J Sport Sci Med 2011;10:105-11.

28. Verhagen AP, de Vet HC, de Bie RA, et al. The Delphi list: a criteria list for quality assessment of randomized clinical trials for conducting systematic reviews developed by Delphi consensus. J Clin Epidemiol 1998;51:1235-41.

29. Maher C, Sherrington C, Herbert R, Moseley A, Elkins M. Reliability of the PEDro scale for rating quality of randomized controlled trials. Phys Ther 2003;83:713-21.

30. Olivo S, Macedo L, Gadotti I, Fuentes J, Stanton T, Magee D. Scales to assess the quality of randomized controlled trials: a systematic review. Phys Ther 2008;88:156-75.

31. Maher CG. A systematic review of workplace interventions to prevent low back pain. Aust J Physiother 2000;46:259-69.

32. Lievense AM, Bierma-Zeinstra SM, Verhagen AP, van Baar ME, Verhaar JA, Koes BW. Influence of obesity on the development of osteoarthritis of the hip: a systematic review. Rheumatology 2002; 41:1155-62.

33. Bronfort G, Hass M, Evans RL, Bouter LM. Efficacy of spinal manipulation and mobilization for low back pain and neck pain: a systematic review and best evidence synthesis. Spine J 2004;4: 335-56.

34. Huisstede BM, Hoogvliet P, Randsdorp MS, Glerum S, van Middelkoop M, Koes BW. Carpal tunnel syndrome. Part I: efectiveness of nonsurgical treatments-a systematic review. Arch Phys Med Rehabil 2010;91:981-1004.

35. Trinh K. Summaries and recommendations of the global impression method. J Acupunct Tuina Sci 2009;7:296-302.

36. Van Tulder MW, Koes BW, Bouter LM. Conservative treatment of acute and chronic nonspecific low back pain: a systematic review of randomized controlled trials of the most common interventions. Spine 1997;22:2128-56.

37. Kaesler D, Mellifont R, Kelly P, Taaffe D. A novel balance exercise program for postural stability in older adults: a pilot study. J Bodyw Mov Ther 2007;11:37-43.

38. Culligan PJ, Scherer J, Dyer K, et al. A randomized clinical trial comparing pelvic floor muscle training to a Pilates exercise program for improving pelvic muscle strength. Int Urogynecol J Pelvic Floor Dysfunct 2010;21:401-8.

39. Kuo Y, Tully E, Galea M. Sagittal spinal posture after Pilatesbased exercise in healthy older adults. Spine 2009;34:1046-51. 
40. Menacho MO, Obara K, Conceição JS, et al. Electromyographic effect of mat Pilates exercise on the back muscle activity of healthy adult females. J Manipulative Physiol Ther 2010;33:672-8.

41. Moreno J, González-Cutre D, Sicilia A, Spray C. Motivation in the exercise setting: Integrating constructs from the approachavoidance achievement goal framework and self-determination theory. Psychol Sport Exerc 2010;11:542-50.

42. Endleman I, Critchley DJ. Transversus abdominis and obliquus internus activity during Pilates exercises: measurement with ultrasound scanning. Arch Phys Med Rehabil 2008;89: 2205-12.

43. Herrington L, Davies, R. The influence of Pilates training on the ability to contract the Transversus Abdominis muscle in asymptomatic individuals. J Bodyw Mov Ther 2005;9:52-7.

44. Petrofsky JS, Morris A, Bonacci J, Hanson A, et al. Muscle use during exercise: a comparison of conventional weight equipment to Pilates with and without a resistive exercise device. J Appl Res 2005;5:160-173.

45. Queiroz BC, Cagliari MF, Amorim CF, Sacco IC. Muscle activation during four Pilates core stability exercises in quadruped position. Arch Phys Med Rehabil 2010;91:86-92.
46. Sewright K, Martens DN, Axtell RS, et al. Effects of six weeks of Pilates mat training on tennis serve velocity, muscular endurance, and their relationship in collegiate tennis players [abstract]. Med Sci Sport Exerc 2004;36(Suppl):S167.

47. Otto R, Yoke M, McLaughlin K, et al. The effect of twelve weeks of Pilates vs resistance training on trained females [abstract]. Med Sci Sport Exerc 2004;36(Suppl):S356-7.

48. Wu HY, Chiang IT. The effects of a chair-based Pilates intervention on postural balance in young-old adults [abstract]. J Aging Phys Act 2008;16(Suppl):S70-1.

49. Hall DW. The effects of Pilates-based training on balance and gait in an elderly population [dissertation]. San Diego: San Diego State Univ; 1998.

50. Kish RL. The functional effects of Pilates training college dancers [dissertation]. Fullerton: California State Univ; 1998.

51. Moseley A, Herbert R, Sherrington C, Maher C. Evidence for physiotherapy practice: a survey of the Physiotherapy Evidence Database. Aust J Physiother 2002;48:43-9.

52. Tinetti ME. Performance-oriented assessment of mobility in elderly. J Am Geriatr Soc 1986;34:119-26. 